DOI 10.1515/linpo-2016-0007

\title{
A comparative study of participles, converbs and absolute constructions in Hindi and Medieval Rajasthani*
}

\author{
Joanna Tokaj \\ Chair of Oriental Studies, Adam Mickiewicz University in Poznań; \\ Faculty of Arts and Philosophy, Ghent University \\ e-mail: joannatokaj@wp.pl
}

\begin{abstract}
The PRO coindexation of converbs and participles in South Asian Languages along with Subject Identity Constraint (Subject Control) violation has been studied by Subbarao (2012) and Murthy (1994). I present the analysis of Medieval Rajasthani data focusing on two construction types - constructions consisting of converbs and participles. I compare my findings on Rajasthani with previous analyses of the Hindi language. I demonstrate that PRO coindexation in Medieval Rajasthani is more strict than in Hindi. Participles are coindexed with a subject or a direct object of the main clause while converbs are most often subject-oriented. Subject Identity Constraint (Subject Control) violation in Medieval Rajasthani (MR) occurs in constructions consisting of participles and converbs. Subject Identity Constraint may be violated in MR in sentences denoting cause and effect and time relation.
\end{abstract}

Key words: PRO coindexation, participles, converbs, absolute constructions, Hindi, Medieval Rajasthani, Subject Identity Constraint violation, Early New Indo-Aryan, historical syntax, converb, absolute construction, clause linking.

\section{Introduction}

In Hindi we find two similar subordinating devices - constructions consisting of converbs and participles. Subbarao (2012) tries to find a functional explanation for the coexistence of those two similar constructions in South Asian Languages (SALs) (Hindi-Ur$\mathrm{du}$ ), i.e. converbs (CVB) (conjunctive participles) and perfective participles (PP). He states that the explanation as to why a language such as Hindi- Urdu or Punjabi has two different constructions which can alternate in some contexts, but not in others, is that the converb is subject-oriented while PRO (an uncase-marked or null case-marked, ungoverned empty element) of the perfective participle can be co-indexed both with the subject and the object of a matrix clause. In the same book he explains cases in which the converb may violate the Subject Identity Constraint which make it a part of an absolute construction.

\footnotetext{
* The research was supported by Polish National Centre for Science grant 2013/10/M/HS2/00553.
} 
In the present article I will take a closer look at PRO-coindexation of converbs and participles in Medieval Rajasthani ${ }^{1}$. I will also show the different relations of converbs and participles to the main arguments in a sentence. To do so, first, I define PRO and the control of the missing argument. Secondly, I briefly explain two main types of clause linkage: coordination and subordination. Next, I show the notions of participles, absolute constructions and converbs giving examples from Hindi, which will be a base for understanding how those verbal forms work in Medieval Rajasthani. Eventually, I demonstrate Subbarao's idea of PRO-coindexation and Subject Identity Constraint (Subject Control) Violation.

\subsection{Control of the missing syntactic argument (PRO)}

In a traditional approach to the control theory we deal with subject or object control (examples are quoted after VanValin 2005):

1. a. Chris tried to see Pat.

b. Kim persuaded Pat to go to the party.

c. Robin promised Sandy to wash the dishes.

"[...] there is a syntactic argument missing from the linked core which must be interpreted as being the same as one of the syntactic arguments of the matrix core. The matrix core argument interpreted as being the same as the missing syntactic argument in the linked core is the controller. Example (1a) shows 'subject' control, since the controller is the 'subject' of the matrix core. The (b) sentence illustrates 'object' control, since the controller is the 'object' of the matrix core. Finally, the (c) example involves 'subject' control." (VanValin 2005: 241)

In his work, Subbarao (2012) states that PRO is an uncase-marked or null casemarked, ungoverned empty element. PRO in the present article will be understood as the syntactic missing argument which can be controlled by a subject or an object.

\subsection{Clause linking}

Traditional approach to the clause linking assumes the existence of two linkage types: coordination and subordination. "Coordination is characterized by the joining of two or more units of equal size and status, and, in the case of whole clauses, all of the clauses have the form of independent main clauses. Subordination, on the other hand, involves the embedding of one unit in another, and the embedded unit does not normally have the form of independent main clauses. The embedded clause functions either as an argu-

${ }^{1}$ In the present article I use the term Medieval Rajasthani to indicate the time period of the texts which I worked on. Historically Rajasthani literature can be divided into three periods: 1. Early period (1100-1450 A.D.); 2. Medieval period (1450-1850 A.D.); 3. Modern period (1850 A.D. till now). The majority of texts which are part of my corpus come from the XV century onwards. There are several works on the early stages of Rajasthani language, among them Khokhlova $(1995 ; 2000 ; 2001)$ on the evolution of Rajasthani morphosyntax, Smith's (1975) work on Middle Marwari, Tessitori's (1914-16) study of Old Western Rajasthani. 
ment, as in complementation, or as a modifier, as in adverbial subordinate clauses." (VanValin 2005:183). ${ }^{2}$

Below, I give explicit examples of coordination and subordination in Hindi (examples are from Kachru 2006):

I. Coordination:

2. tum ghar mem bețho aur maim bāhar kā sab

You.2.PL home in sit.IMP and I outside of.M.SG all

kām kar āūm ${ }^{3}$

work do come.SUBJ.1SG

'You stay at home and I will go out to get all the work done.'

II. Subordination:

3. sigret pinā ek nașā hai jo ādmi ke

Cigarette smoke.INF an addiction be.PRES.SG REL human of.M.OBL

śarīr ko nașt kartā hai.

body.M.SG.OBL ACC destruction do.IMP.M.SG PRES. SG

'Smoking is an addiction that destroys the human body.'

In the upcoming sections I will show that participles and converbs in Hindi are mainly subordinating devices.

\subsection{Participles in NIA}

Haspelmath defines participles as follows: "Participles are verbal adjectives. As such, they share many of the morphosyntactic properties of adjectives, in particular the ability to be used attributively, functioning as relative clause heads." (Haspelmath 1995: 18). When it comes to New Indo-Aryan languages, the situation is more complex.

Participles both in Hindi and in Medieval Rajasthani are derived from verbs: present and past. Participles in NIA (examples in Hindi) can be divided into two main categories according to the criteria of tense/aspect, i.e. imperfective and perfective. Regarding the syntactical construction, both types of participles are used predicatively and attributively. (Pořizka 2000: 78). Both type of participles have two functions: adjectival and adverbial. (Kachru 2006: 226-230).

${ }^{2}$ However, according to Van Valin (2005) there is one more type of clause linkage relation, i.e. cosubordination. In cosubordination "units of equivalent size are joined together in a coordinate-like relation but share some grammatical category, e.g. tense or mood." and "these constructions are therefore a kind of dependent coordination."(VanValin 2005:187). I am aware of ongoing discussion concerning cosubordination of converbs, however in the present paper I take the traditional approach to the converbs, i.e. that they are subordinating devices.

${ }^{3}$ In the paper I used the following abbreviations: 1 - first person; 2 - second person; ACC - accusative; ADV - adverbial; AG - agent; CAUS - causative; CVB - converb; DAT - dative; ERG - ergative; F - feminine; foc - focus; FUT - future; GEN - genitive; IMP - imperfective; INF - infinitive; INS - instrumental; M - masculine; NOM - nominative; OBL - oblique; PL - plural; PRES - present tense; PRF - perfective; PROG - progressive; PST - past; PTCP - participle; REL - relative; SG - singular; SUBJ - subjunctive. 
The imperfective participle has the form verb-tā $(h u \bar{a})$, which is inflected for gender, number and case. The perfective participle has the form verb-a $(h u \bar{a})$, which is inflected for gender and number. (Kachru 2006: 226-230).

The adjectival function of both participles in Hindi can be illustrated as follows:

I. Imperfective adjectival participle:
4. $\operatorname{rota}$
(huā)
ladk $\bar{a}$
cry.M.3-SG.IMP.PTCP be.M.3-SG.PST boy.M.SG.NOM
'crying boy'

II. Perfective adjectival participle:
5. pakā huā
cook.M.3-SG.PERF.PTCP be.M.3-SG.PST food.M.SG.NOM
'the cooked food'

The adverbial participle is used as an adverb. It is worth noticing that : "[...] the adverbial participle, when constructed predicatively, defines the main verb and is not bound to any agreement with any noun, as it is indeclinable." (Porrizka 2000: 85). The predicative adverbial participle is either related (qualifying the subject in the nominative, or the agent in the case of agent, or the direct object of the main verb) or unrelated (qualifying an agent of its own) (Pořizka 2000:79). Below I give examples of related participles from Hindi (examples from Kachru 2006):

I. Related imperfective adverbial participle (IAP):

6. Ve log bātem karte hue jā rahe

Those people talk.F.PL do.IMP.PTCP.OBL be.PST.OBL go PROG.M.PL

the unhomne mujhe nahịm dekhā.

PST.PL they.OBL.AG I.OBL.DAT not see.PERF.M.SG

'Those people were talking as they walked; they did not see me.'

7. larkī maze mem gātī huī/

girl.F.SG enjoyment.M.SG.OBL in sing.IMP.PTCP.F/

gāte hue jhülā jhūl rahī hai.

sing.IMP.PTCP.OBL swing.M swing PROG.F.SG PRES.SG

'The girl is swinging in the swing with enjoyment.'

According to Kachru (2006) imperfective adverbial participle: "[...] may have invariable (oblique) form -te hue $(6 ; 7$.) or it may agree with the understood subject of the participial verb (7.)[...].”.

II. Related perfective adverbial participle (PAP):

8. gāmv ke sab log naye kapre

village.M.SG.OBL of.OBL all people new.M.PL cloth.PL

pahne hue mele jạ rahe haim

wear.PERF.PTCP.OBL fair.M.OBL in go PROG.M.PL PRES.PL

'All the people of the village are going to the fair dressed in new clothes.' 


\title{
1.3.1. Unrelated participles as a type of absolute constructions
}

In addition to related adverbial participles, there are also unrelated adverbial participles in Hindi. Adverbial imperfective and perfective participles can be used in an absolute construction (AC). "When the participle has a subject of its own, different from the subject (and the object) of the main verb in the sentence, then the participle is rightly called an 'absolute participle'." (Pořizka 2000: 68). As Haspelmath noticed: In the term absolute construction, absolute is generally taken to mean "not sharing an argument with the main clause' [...]. (Haspelmath 1995: 45-46). According to Bubenik (1998) one considers a construction absolute when the subjects of the two clauses are not coreferential. "The head noun and its participle form a special type of a subordinate clause which could express an event contemporary with or anterior to that in main clause." (Bubenik 1998:197). An absolute construction functions as a subordinate clause with some non-specific adverbial relation to the main clause (Haspelmath 1995:27). The core structure of an absolute construction is a noun combined with a participle in an oblique case (Bauer 2000: 262).

Ruppel (2013) gives an overview of ACs' characteristics stated by other authors: "Some authors concentrate on (or also mention) the fact that ACs stand 'as attributes to a whole clause' or 'syntactically independent' from their matrix clause. Others focus on the necessity that the subject of the AC be absent from the matrix clause.". She criticizes this way of describing ACs giving her own definition:

\begin{abstract}
"Absolute constructions are temporal expressions with non-temporal heads. Normally, nominal expressions of time involve nouns that have some temporal dimension to their semantics, as in at dawn, on Monday, during the lecture. ACs on the other hand have as their heads nouns which do not denote events but things (whether animate or not): [...] Romulo rege "with Romulus as king, when Romulus was king', sû́rye udyatí (sunLoc.Sg up-goingLoc.Sg) 'at the rising sun, at sunrise'. Although the semantics especially of ACs in the Classical stages of each language may receive a strong causal or concessive nuance, ACs still basically denote a point or period in time. Because the head nouns do not have any temporal semantics, they cannot fulfil this function on their own and need to be 'put into time', so to speak, by the accompanying attribute (usually a participle, in Latin also an adjective or another noun). The semantic necessity of these attributes for the expression as a whole to make sense is what creates their 'dominance': they are necessary in the same way as a predicate is required in a verbal clause (the non-nominal counterpart of temporal expressions).” (Ruppel 2013:30-31)
\end{abstract}

Examples of absolute constructions in Hindi with both imperfective and perfective participles are presented below.

I. The absolute construction (AC) with the imperfective adverbial participle:

9. Jāte jāte rāste mem ek jagaha baụ̄ badabū go.IMP go.IMP road.OBL in one place big bad-smell àne lagī

come.INF.OBL begin.PRF.F.3SG

'While going, a bad smell began to be felt in one place on the road.' (Pořizka 2000: 68) 
II. The absolute construction with the perfective adverbial participle:

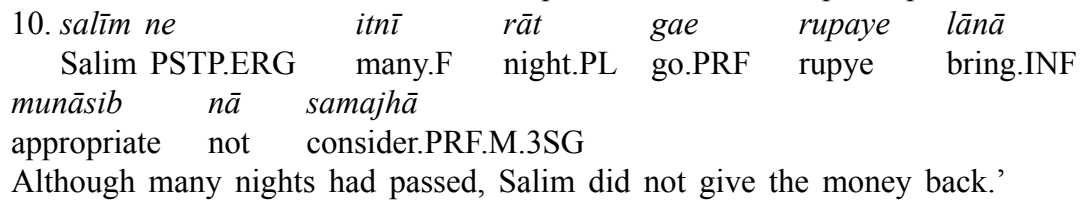

Lit. 'Many nights passed, Salim did not consider it appropriate to give the money back.' (Porrizka 2000: 86)

Example (9) indicates that the action of the dependent clause happens simultaneously to the action of the independent clause, hence providing additional (not required) information. In other words, the action described by the absolute construction with the imperfective adverbial participle is contemporary to that in the main clause. The absolute construction with the perfective adverbial participle (10) does not express the simultaneity of two actions. The action described in the dependent clause precedes the action of the independent clause, thus this construction expresses a sequence of events.

At this point I would like to mention one more participial construction in Hindi which expresses temporal adverbial relation. The construction consists of imperfective participle in oblique case -te and the noun samay or vaqt 'time'.

\section{Sägar kināre jāte samay dhyān rakhem ${ }^{4}$ \\ Ocean shore.PL go.IMP.OBL time care keep.PL.SUBJ}

'Be careful while going to the ocean'

This construction resemble the usage of absolute construction. Similarly to absolute construction based on imperfective participle, this construction also indicates an action contemporary to that in the main clause. However, we can see that in this case the adverbial phrase is subject-oriented, unlike absolute constructions.

Now I move to defining another NIA subordinating device, i.e. converb.

\subsection{Converbs}

A converb is a non-finite, non-tensed verbal form (Subbarao 2012) which often receives perfective reading (Davison 1981; 1986) obeying the same subject rule in most cases. Depending on the language the converbal marker can be a free, or a bound morpheme (Subbarao 2012). The main arguments marking is dependent on the transitivity of the main verb (exceptions can be found in Nepali (Peterson 2002)) not on the transitivity of the converb.

A number of studies has proved that converbs usually function as a subordinator and an adverb. Haspelmath (1995:3) defines "converb" as "a nonfinite verb form whose main function is to mark adverbial subordination. Another way of putting it is that converbs are verbal adverbs, just like participles are verbal adjectives."

${ }^{4}$ Example is from http://hindi.webdunia.com 
Davison distinguishes three main syntactic functions of a Hindi converb, i.e. coordinating, subordinating and adverbial function. However, she claims that all of them are more precisely the degrees of subordination (Davison 1979, 1981). The examples of Hindi converbs whose PRO is coindexed with the matrix subject are presented below:

I. Coordinating function:

$\begin{array}{lllllll}\begin{array}{c}\text { 12. baniye } \\ \text { shopkeeper }\end{array} & \text {-GEN } & \text { bețe } & \text { ne } & {[\text { cițthi } \bar{l}} & \text { likhkar] } & \text { dia } k \\ \text {-ERG } & {[\operatorname{letter(F)}} & \text { write-CVB] } & \text { post office }\end{array}$

mem $\mathbf{d} \bar{a} \bar{l}$

-in throw.PRF.F.SG

'The shopkeeper's son wrote a letter and mailed it at the post office.'

Literally: 'The shopkeeper's son, having written a letter, mailed it at the post office.'

(Davison 1981:1)

This example shows a coordinating function of the Hindi converb. The converb likhkar expresses a coordinate relation between clauses taking the "and then" meaning. The sentence may be compared with the construction which lack converb:

\begin{tabular}{|c|c|c|c|c|c|}
\hline $\begin{array}{l}\text { 13. baniye } \\
\text { shopkeeper }\end{array}$ & $\begin{array}{l}k e \\
\text {-GEN }\end{array}$ & $\begin{array}{l}\text { bete } \\
\text { son-OBL }\end{array}$ & $\begin{array}{cl}n e & \text { cittthī } \\
\text {-ERG } & \text { letter(F) }\end{array}$ & $\begin{array}{l}\text { likh̄̄ } \\
\text { write.PRF.F.SG }\end{array}$ & $\begin{array}{l}\text { aur } \\
\text { and }\end{array}$ \\
\hline $\begin{array}{l}s \text { ne } \\
\text { e.OBI }\end{array}$ & d़a $k$ & & $\begin{array}{ll}m & d \bar{a} l \bar{\imath} \\
& \text { throw } \mathrm{P}\end{array}$ & & \\
\hline
\end{tabular}

'The shopkeeper's son wrote a letter and mailed it at the post office.'

If the subjects of the two clauses are not the same, it is necessary to use coordinate structure with clauses containing finite verbs:
14. baniye ne cițhī likhī aur phir bețe ne shopkeeper ERG letter write.PRF.F.SG and then son.OBL ERG
ḍāk mem dọalì
post office in throw.PRF.F.SG
'The shopkeeper wrote a letter and his son mailed it at the post office.'
(Davison 1981:1)

II. Subordinating function:
15. mujhe un cīzom me.DAT those.OBL things.PL.OBL
ko dekhkar bahut
gussā $\bar{a} y \bar{a}$
anger come.PRF.M.SG
'When I saw those things, I became very angry.'
'Having seen those things, I became very angry.'
(Davison 1981: 1)

The example above presents subordinating relation between the main clause 'I became very angry' and the dependent clause 'having seen those things.' The other construction, devoid of converb, can be used to express semantically the same message: 
16. un cìzom ko dekhne parmujhe

those.OBL things.PL.OBL POST.DAT see.INF.OBL on me.DAT

bahut gussā āya

great anger come.PRF.M.SG

'I got very angry, when I saw those things.'

(Davison 1981: 1)

III. The adverbial function:

17. daurke jāo varnā narāj hümgā run.CVB go.IMP or (else) annoyed be.FUT.M.SG

'Go quickly or I will be annoyed.'

(Davison 1981: 2)

Usually converbs are translated as 'having+PRF' (e.g. having eaten) but in this example the converb takes the adverbial reading of 'quickly'. To contrast the converbal construction with the one without a converb, I quote the example:

18.jaldī se cāle jāoge to mujhe acchā nahīm

hurry with go.PRF go.FUT.2PL then me.DAT good not

lageg $\bar{a}$

strike.FUT.M.3SG

'If you leave in a hurry, I won't be pleased.'

(Davison 1981: 2)

Here we deal with a correspondence between daurke and jald $\bar{\imath}$ se (it is a combination of a nominal jald $\bar{l}$ 'haste' and instrumental postposition se) on the semantic level. But both constructions are not syntactically alike.

Finally, I move to describing the problem of PRO coindexation raised by Subbarao (2012).

\subsection{Converbs, perfective adverbial participles and absolute constructions in Indian languages- PRO coindexation}

According to Subbarao (2012) the subject of the converbal chain is PRO, i.e. a null element. When there are two arguments (subject and object) in the matrix clause, most often it is the subject which can be coindexed with PRO of the $\mathrm{C}$ (converb) clause (exceptions can be found in some languages, for example in Kashmiri). However, the perfective adverbial participle (PAP) may be coindexed with either the matrix subject or the object (Subbarao 2012: 264). What is more, PRO of PAP may be indicated by the position of PAP in the sentence. In Hindi, PAP's position to the left of the matrix clause makes PRO more likely to coindex with subject. PAP to the right of direct object or matrix verb phrase makes PRO more ambiguous, it can be coindexed both with subject and object. However, when an absolute construction is concerned, there is an explicit subject which is different from that of the main verb. 
As shown in the Hindi examples below the position of the converb does not play a role in coindexing. In other words, converbs are prone to take the subject of the main verb regardless their position in a sentence. In all three cases, the converb coindexes with the subject, not with the object.

\section{9. kamre mẽ baith kar ham ne choțe baccõ ko dekhā} room in sit CVB we ERG small children ACC saw

'We saw the small children while we were sitting (seated) in the room.'

'*We saw the small children while they were sitting (seated) in the room.'

20. Ham ne kamre mẽ baiț kar choțe baccõ ko dekhā We ERG room in sit CVB small children ACC saw

21. Ham ne choțe baccõ ko dekhā kamre mẽ baiț kar we ERG small children ACC saw room in sit CVB All examples are from Subbarao (2012: 265-266).

The coindexation of PAP is more complex. The position to the left of the main clause implies PAP's PRO coindexation with the subject of the main clause, as exemplified in (22) and (23). When PAP appears to the right of a direct object or main clause we deal with an ambiguous situation. PRO can be coindexed with both subject or object, see ex.(24)-(25) from Hindi:

22. ham ne kamre mẽ baith-e hue choțe baccõ ko dekhā we ERG room in sit.PERF.PTCP small children ACC saw 'We saw the small children while we were sitting (seated) in the room.'

'*We saw the small children while they were sitting (seated) in the room.'

23. kamre mẽ baith.e hue ham ne chote baccõ ko dekhā room in sit.PERF.PTCP we ERG small children ACC saw

'We saw the small children while we were sitting (seated) in the room.'

'*We saw the small children while they were sitting (seated) in the room.'

24. ham ne choțe baccõ ko kamre mẽ baith.e hue dekhā we ERG small children ACC room in sit. PERF.PTCP saw

'We saw the small children while we were sitting (seated) in the room.'

'We saw the small children while they were sitting (seated) in the room.'

25. Ham ne choțe baccõ ko dekhā kamre mẽ baithe hue we ERG small children ACC saw room in sit.PERF.PTCP

'We saw the small children while we were sitting (seated) in the room.'

'We saw the small children while they were sitting (seated) in the room.'

All examples are from Subbarao 2012: 269-271 


\subsection{Subject Identity Constraint (Subject Control) violation}

Even though PRO of a converb is usually controlled by a subject of the main clause there are some exceptions when a converb can have its own subject. The Subject Identity Constraint (SIC) of a converb may be violated in few cases:

Animacy plays an important role in the violation of SIC. According to Subbarao (2012) when the embedded sentence denotes a non-volitional action and the subject of the embedded clause is -animate, the violation of Subject Identity Constraint is permitted. When subject is +human, violation is not permitted.

Kashmiri (IA)

26. rüd pya- th khot jān phasal

rains fall- CVB grew well crops

Literally: 'Rains having fallen, the crops grew well.' (Subbarao 2012:275)

According to Lalitha Murthy (1994) lexical subjects occur only in such converbal clauses which express cause and effect relation, temporal clauses and clauses with opposite verbs.

I. Cause/effect

Sinhala (IA)

27. [ammai leḍ welā] gedəra sērama wceda karanne api! mother sick become.CVB house all work do.foc we 'With mother sick, it is we that (have to) do all the housework.'

(Gair and Paolillo 1997: 49)

II. Temporal clauses:

Hindi-Urdu (IA)

28. āthi baj kar das minatj hue

eight strike CVB ten minutes happened

Literally: 'Eight having struck, ten minutes occurred.'

'It is ten minutes after eight.'

III. Contrastive statement

Telugu (DR)

29. andarüi annam tin- $i$ pellikodukuj tin- a lēdu

all food eat- CVB bridegroom eat- ? not

'Everybody had eaten but the bridegroom had not.'

Based on the Subbarao's and Murthy's theories, I look for possible ways of PRO coindexing in participial, converbal and absolute constructions in the Medieval period of the Rajasthani language. First, in the section 3.1 I analyze PRO coindexation in participial constructions. In this paper I show that unlike Hindi, Rajasthani is more strict in subject/object control of participles. In Section 3.2 I focus on converbs in Rajasthani. Next, in Section 3.3 I present the existence of absolute constructions in Rajasthani and try to ascribe the Subject Identity Constraint (Subject Control) violation to those forms. Finally, I sum up my findings and I try to answer if there is any functional explanation of co-existence of two subordinating devices. 


\section{Methodology}

My data is an annotated corpus of Medieval Rajasthani, consisting of about 10000 words, extracted from short prose texts ranging from the 14th to the 18th century (Bhānāvat and Kamal 1997-1998). The corpus has been annotated by means of IATagger (Jaworski 2015) at the level of morphosyntax and semantics.

Using IATagger I generated sentences consisting of participles and converbs. Next step was to select generated forms in terms of arguments' control which I had to do manually. In the end, I had a list of different possible scenarios of PRO coindexation. What is more, I went through all the generated absolute constructions and I analyzed all the forms basing on Subbarao's and Murthy's findings.

\section{Results}

\subsection{Participles in MR:}

Participles in Rajasthani behave like participles in Hindi. Participles in Medieval Rajasthani may be divided into two main categories concerning tense/aspect: imperfective participles and perfective participles. Imperfective participles function mainly as adjectives modifying a noun. Perfective participles function mainly as adjectives, main verbs, adverbs.

\subsubsection{Related participles and PRO coindexation}

PRO coindexation in MR seems to be quite strict. There are no instances of ambiguous PRO coindexation such as in Hindi. Participles can be coindexed with a subject of the main clause or an object of the main clause. Examples of related participles from Rajasthani are presented below.

I. Imperfective participle coindexed with a matrix (= main clause) subject:

$\begin{array}{cll}\text { 30. sukha vilasatā } & \text { vayarasena } & \text { nagarī mähi ...rahiu } \\ \text { happiness enjoy.IMP.PTCP } & \mathrm{V} . & \text { town in stay.PRF.M.SG }\end{array}$

,Being happy, Vayarsena stayed in a town'.

II. Perfective participle coindexed with a matrix subject:

31. teṇi pātisāha āyām sạmtari sata chāṃ̣ại nah̄ this.OBL shah come.PRF.OBL.PL meantime honourleave.3SG.PRS not

,When the king came, he did not abandon his honour'

III. Imperfective participle coindexed with a matrix object:

32. taim amhe ihām chatā jāniya you.INS we.NOM. here be.IMP.PTCP know.PRF.M.PI

'You knew we were here.'

In the corpus there are no instances of perfective participle coindexed with a matrix object. 


\subsubsection{Unrelated participles}

Tessitori (1914-16) indicates that both imperfective and perfective adverbial participles in Old Western Rajasthani are forms of an absolute genitive construction. Similarly to Hindi absolute constructions appear to the left of the main clause. What is more, ACs in Rajasthani show the same functions as the $\mathrm{AC}$ in Hindi. The imperfective adverbial participle in (33) indicates that the action of shooting happens at the same time as the action of the main verb "break". The perfective adverbial participle in (34) shows a sequence of events. The action described in the dependent clause precedes an action of an independent clause.

I. Imperfective adverbial participle:

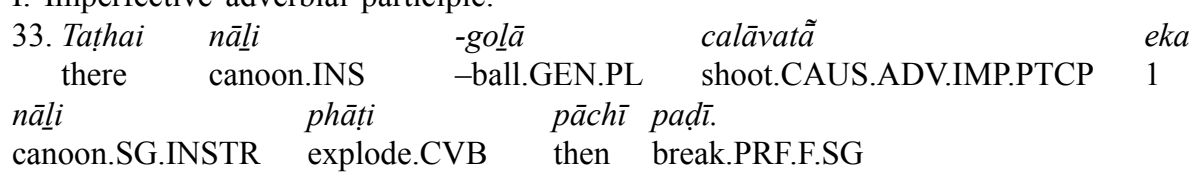

There [while] shooting cannonball from cannon, one cannon having exploded broke. (R.G. 42)

II. Perfective adverbial participle:

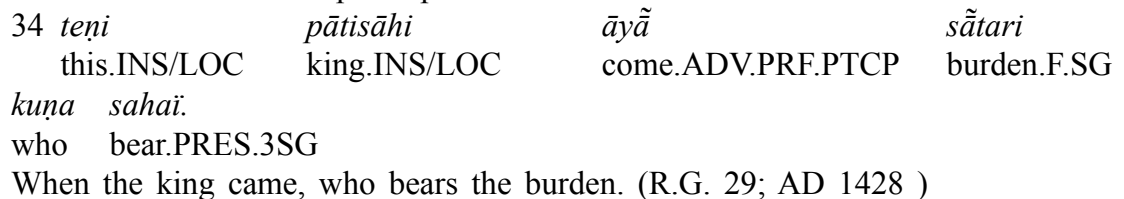

The above examples suit Ruppel's definition of absolute constructions, i.e. ACs are temporal expressions with non-temporal heads. ACs based on participles define some point of time.

\subsection{Converb and its functions in MR:}

Converbs in Medieval Rajasthani are non-finite, non-tensed, perfective verbal forms. The subject of a converbal clause is most often a null element, and it is PRO. The converbal phrase is subject-oriented. Since the converb does not have any tense marker of its own, the tense of the main clause has a scope over the converbal phrase.

Among the main syntactic functions of converbs in MR are the subordinating function (35) and the adverbial modification (36) of the action described by the main verb.

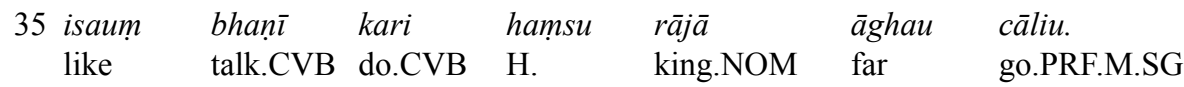

'Having said this king Hansu (S) went further'. 14th c. (R.G.)

36. tiṇi dārū pātisāha bāli

he.3SG.INSTR gunpowder.NOM shah.NOM burn.CVB kill.M.SG.PRF

'This gunpowder has killed shah by burning.' (RG 16/17th c.) 


\subsection{Converbs and absolute constructions in MR- PRO coindexation}

In this section I try to show that the Subject Identity Constraint violation presented by Subbarao and Lalitha Murthy concern both constructions in MR: absolute constructions based on participles and converbs.

\subsubsection{AC based on IAP and PAP}

There are several instances of ACs based on imperfective participles in the corpus. In my data we find subjects of embedded clauses which are both overt and covert, and they are thuman/+animate. Imperfective participles used in absolute constructions in Rajasthani imply +volitional actions. Similarly to Hindi, in Rajasthani the relation between embedded clause and main clause indicates that actions take place at the same time or shows cause and effect relation (the only point of the SIC violation).

I. Imperfective PTCP used absolutely (I repeat the example given in 33)

37. tathai nāli-golāa calāwatāa năli

There cannon-balls shoot.CAUS.ADV.IMP.PTCP one cannon

phāți pachī paṛī.

explode.CVB back fall.PRF.F.SG

'There when the cannon-balls were shooting one cannon exploded and fell scattered.' 16/17th c. (R.G.)

In the example above there is an imperfective participle used in an absolute construction. The participle comes from a transitive, causative verb which denotes +volitional action. Causativity of the participle indicates that its subject is +human. The action in the embedded clause may indicate the cause of the main's sentence effect or simply that both actions (of the embedded and main clause) take place at the same time.

There are very few occurrences of a perfective adverbial PTCP used in absolute constructions in the corpus. Examples found in the corpus consist of intransitive perfective participles which come from verbs 'to come'(38), 'to go/past/last'. Subjects of embedded clauses are thuman and they denote +volitional actions. The only example which suits Lalitha Murthy's violation theory is one occurrence of a sentence with a time reference which has a -animate and -volitional subject (39).

II. Perfective PTCP used absolutely

38. teṇi pātisāha āyāṃ sāṃtari sata chāṃ̣ai nahī,

This shah come.ADV.PRF.PTCP meantime honour Leave not

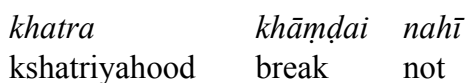

'When the shah came in the meantime, he does not leave his honor, he does not break his kshatryahood' (= heroism). 15th c. (R.G.) 


\section{9. kāla gayā humtāa ūtāwāla asawāra ke-eka \\ Time.NOM.SG.M go.PRF.OBL.M be.IMP.PTCP.OBL.M speedy rider.NOM.PL.M some rāya rahaim miliyā.}

king.OBL.SG.M DAT meet.PRF.PL.M

'After some time some speedy riders met the king.'

Absolute constructions occur to the left of the main clause just like in Hindi.

\subsubsection{ACs based on converbs}

Converbs in MR can be part of absolute constructions as well. It is possible for the so called dropped argument not to be coreferential with the subject of the main clause.

The Subject Identity Constraint of a converb may be violated in MR in sentences denoting cause and effect. The subject of the matrix and embedded clauses may be non-identical and they may be both thuman. In the example (41) we see that the controller of the converb is different from the subject of the main verb. Moreover, even though the controller/subject of the converb is +human, we deal with absolute construction which follows cause and effect relation (of the SIC violation). Converbs used absolutely occur to the left of the main verb.

\section{0. $\operatorname{ara}$ hemū Pạn̄ipamtha $\bar{a} i \quad$ derā pariya}

and hemu[M]NOM.SG Panipat come. CVB camp[M]NOM.PL fall.PST.M.PL And after that Hemu had come to Panipat, the camps were established.' 16/17 ${ }^{\text {th }}$ c. (R.G.)

41. $t i$ raja=nai vacani karī

these man[M]NOM.PL king=OBL speech[F]NOM.SG do.CVB

samgha $=m \bar{a} h i \quad$ gayā

community=in go.PST.M.PL

'These men on hearing the king's speech (lit. of the king having spoken) went happy to their community.' $16 / 17^{\text {th }}$ (R.G.)

Here again we can observe that absolute constructions have a lot to do with describing time.

\section{Conclusions}

In the present article, I focused on non-finite verbal forms in Medieval Rajasthani, in particular on converbs and imperfective and perfective participles. I briefly described the participial and converbal constructions in NIA Hindi to create a base for comparison Hindi with Rajasthani. I gave an overview of the Subject Identity Constraint and its violation in Hindi which was necessary to introduce the notion of absolute constructions based not only on participles but also on converbs. Thanks to that I compared Rajasthani participial, converbal and absolute constructions to those present in Hindi.

Subbarao noted that the functional explanation for the coexistence of two similar constructions (converbs and perfective participle) is that the converb is usually subject-ori- 
ented and the perfective participle can be coindexed with both the subject and the object of a main clause. It seems that in Rajasthani we deal with an even less ambiguous situation than in Hindi-Urdu. Participles are related to a subject or a direct object of the main clause while converbs most often are coindexed with subject of the main clause. The position of participles and converbs in a sentence does not influence the PRO coindexation. However, similarly to Hindi-Urdu we may find violation of the SIC of both constructions. When the SIC is violated we deal with absolute constructions which always occur to the left of the main verb.

In MR imperfective and perfective participles may be adjectival or adverbial, they can be used attributively or predicatively. MR seem to be more strict when it comes to the PRO coindexation of participles than Hindi. Participles take a subject or an object of the main clause.

Adverbial participles may be a part of absolute constructions, then they don't share a subject with the subject of the main verb. Similarly to Hindi, the absolute construction with an adverbial imperfective participle expresses an event contemporary to that in the main clause providing some extra information, while AC with APP an event anterior to that in the main clause. Among patterns of SIC violation two of them were spotted in the corpus and constrained to participles used absolutely: cause and effect (AIP, APP) and time relation (APP).

Converbs in MR in most of the cases follow the SIC. However, although it is extremely rare, converbs in MR are parts of absolute constructions too. Subject Identity Constraint of a converb may be violated in MR in sentences denoting cause and effect.

\section{References:}

Bauer, Brigitte. 2000. Archaic Syntax in Indo-European. The Spread of Transitivity in Latin and French. Berlin - New York: Mouton de Gruyter

Bubenik, V. 1998. A historical syntax of late Middle Indo-Aryan (Apabhramsa). Amsterdam: Benjamins.

Davison, Alice. 1979. Some mysteries of subordination. Studies in Linguistic Sciences, Vol. 9, No. 11979.

Davison, Alice. 1981. Syntactic and semantic indeterminacy resolved: a mostly pragmatic analysis for the Hindi conjunctive participle. In: Cole Peter (ed), 1981. Radical pragmatics. New York: Academic Press, $101-128$.

Dwarikesh, Dwarika P. 1971. The historical syntax of the conjunctive participial phrase in the New Indo-Aryan dialects of the Madhyadesa ( Midland ) of Northern India.

Gair, James W. and Paolillo, John C. 1997. Sinhala. München: Lincom Europa.

Haspelmath, Martin 1995. The converb as a cross-linguistically valid category. In Converbs in Cross-Linguistic Perspective Structure and Meaning of Adverbial Verb Forms-Adverbial Participles, Gerunds. Empirical Approaches to Language Typology 13

Kachru, Yamuna. 2006. Hindi. (London Oriental and African language library, 12.) Philadelphia: Benjamins

Khokhlova, Ludmila V. 1995. The development of patient-oriented constructions in late Western NIA Languages. Osmania Papers in Linguistics 21, 15-51.

Khokhlova, Ludmila V. 2000. Typological evolution of Western NIA languages. Berliner Indologische Studien (BIS) $13 / 14,117-142$.

Khokhlova, Ludmila V. 2001. Ergativity attrition in the history of Western New Indo -Aryan languages (Punjabi, Gujarati and Rajastahani). The Yearbook of South Asian Languages and Linguistics, 159-184.

Murthy, Lalitha B. 1994. "Participial constructions: A cross-linguistic study". unpublished PhD dissertation, New Delhi: University of Delhi 
Peterson John. 2002. "The Nepali converbs: a holistic approach.” In: RajendraSingh (ed.): Yearbook of South Asian Languages and Linguistics. New Delhi/Thousand Oaks/London: Sage Publications. 93-133.

Pořizka, Vincenc. 2000. Studies in the Bhagavadgita and New Indo-Aryan languages. Prague: Oriental Institute Academy of Sciences of The Czech Republic

Ruppel, Antonia. 2013. Absolute Constructions in Early Indo-European. New York: Cambridge University Press

Subbarao, Karumuri. V. 2012. South Asian Languages: A Syntactic Typology. New York: Cambridge University Press

Tessitori, Luigi. P. 1914-16. Notes on the Grammar of the Old Western Rajasthani with Special Reference to Apabhramsa and to Gujarati and Marvari.

Van Valin, Robert D. Jr. 2005. Exploring the Syntax-Semantics Interface. New York: Cambridge University Press

\section{Primary sources:}

Bhānāvat, Narendra and Kamal, Lakshmi (eds.). 1997-1998. Rājasthānī gadya: vikās aur prakāś. 